\title{
Relationship Between Lecturer Competency and Student Achievement Mediated by Student Satisfaction on Learning Process
}

\author{
Herdiyana*, Rita Istiana \\ Pakuan University \\ Bogor, Indonesia \\ *herdiyana@unpak.ac.id,rita_istiana@unpak.ac.id
}

\begin{abstract}
One indicator of the success of a college is the quality of students. One of the qualities of students can be seen from the achievement of learning achieved. Student learning achievement will be excellent if students are satisfied with the learning process that is followed. One component that can provide satisfaction to students is the competence of lecturers. This study aims to analyze the effect of lecturer competence on student learning outcomes mediated by student satisfaction with the learning process. This study population was 371 student class 2017 of the Management department, Faculty of Economics, Pakuan University. The sampling method using cluster sampling and the method of determining the number of samples using Slovin with a significant level of $10 \%$ obtained a sample of 79. Data collection using questionnaires and secondary data. The method of analysis used correlation and regression analysis. The results showed that the lecturer competence have not a significant correlation and influences to student achievement. Student satisfaction in the learning process have not a significant correlation and affects to learning achievement. The competence of lecturers has a significant correlation and influences on student satisfaction.
\end{abstract}

Keywords-lecturer competence, student satisfaction, student learning achievement

\section{INTRODUCTION}

The quality of a nation depends on human resources. In this regard, the Indonesian nation needs to improve the quality of its human resources to be able to compete in the era of globalization. Improving the quality of human resources can be done through education. One of the benchmarks in achieving the success of educational goals is the learning achievement used by formal educational institutions to produce graduates who are competent according to their fields with the standards of the national education system. Therefore, learning achievement is an interesting problem to study.

Pakuan University is one of the formal educational institutions that have basic norms of educational, scientific, and religious life. These basic norms are manifested in the actions of all academicians inside and outside the campus, as well as animating the basic ideas, design, and implementation of the campus curriculum. Pakuan University has the vision to become a university that is superior, independent, and of character as well as having a vision and also having a mission to prepare human resources who explore, develop and apply science, technology, and art based on wise and wise attitudes. One of the Study Programs at Pakuan University is the Management Study Program at the Faculty of Economics (FE). The Management Study Program in 2020 is expected to graduate as many as 370 people [1].

The achievement of learning objectives in the Management Study Program is determined by the level of student learning achievement which can be seen from the learning evaluation score, both the evaluation score in each semester and the cumulative Achievement Index (GPA) value recapitulation. GPA is an evaluation of the results carried out through a study of student performance including the results of learning activities in each course and the entire course. This indicates that the quality of education can be seen from the average value of the achievement of the Grade Point Average (GPA).

Based on the 2018 Faculty of Economics Strategic Plan, in the next 5-year target, the average expected GPA is at least 3.20 (on a scale of 4), the baseline is 3.20. So, a GPA greater than $3.20(\geq 3.20)$ as generally expected by the Management Study Program, namely producing students with high GPA scores and making graduates into 1) managers in business (finance, marketing, resources human resources, and operations); 2) scientists or consultants in the field of business management (finance, marketing, human resources, and operations); and 3) entrepreneur. The following (Table 1) is the average GPA of a Management Study Program graduate in the last five years. 
TABLE I. GPA OF MANAGEMENT STUDY PROGRAM GRADUATES IN THE LAST 5 YEARS

\begin{tabular}{|l|l|}
\hline \multicolumn{1}{|c|}{ Years } & Average Student Achievement Index \\
\hline 2015 & 3.13 \\
\hline 2016 & 3.14 \\
\hline 2017 & 3.19 \\
\hline 2018 & 3.10 \\
\hline 2019 & 3.15 \\
\hline \multicolumn{2}{|c|}{ Source: Academic Information System \& FEUP 2020 Students }
\end{tabular}

Based on table 1. It can be seen that the average GPA of Management Study Program graduates in the last five years has fluctuated. Besides, based on the results of tracing the graduate data, the number of graduates who were below the average from 2015 to 2019 were respectively: $42 \%, 52 \%$, $48 \%, 49 \%$, and $50 \%$.

This research is important to do because the results of this research can be used as the basis for education managers, especially the Management Study Program in increasing student achievement to match the 2018 Faculty of Economics Strategic Plan. Efforts that can be made to improve student achievement include improving human resources, namely lecturer competence as well as student satisfaction in both academic and non-academic services.

Student success can be seen from the learning achievements they have achieved. To achieve good achievement cannot be separated from the factors that affect the learning process. Many theoretical views and practical studies explain the factors that influence achievement [2]. The factors that affect learning outcomes are classified into two, namely internal factors and external factors. Internal factors are factors that come from the individual subject of learning, namely factors that are physical and psychological. Physical factors include fatigue, health, and other physical conditions. Meanwhile, psychic factors include interest, motivation, selfsatisfaction, maturity, self-efficacy, learning independence, and others [3]. External factors are factors that come from outside the individual subject of learning, such as lecturer competence, teaching materials, curriculum, teaching and learning facilities, environment, and others [4].

Researchers suspect that in the management learning process, internal factors are needed, namely student satisfaction in service while studying on campuses such as satisfaction in the academic field in class such as meeting learning and non-academic needs such as administrative services. Besides that, what determines student achievement is the competence of the lecturers. One of the benchmarks that can be seen is that the lecturer is competent, namely how far he has mastered the material and applies the appropriate learning model for the material being taught. If a lecturer does not master the material to be taught, it will have an impact on the academic quality of students. Competent educators are educators who have the skills to provide reinforcement, questioning skills, variation skills, explanation skills, and skills. opening and closing lessons [4].
Lecturer competencies into 4 competencies; namely 1) pedagogical competence, namely the ability to process the development of courses in the curriculum, the development of teaching materials, and designing learning strategies, 2) professional competence, namely the ability to master materials in any field of study with various other scientific substances, 3) social competence, namely the ability conduct social relations with students, colleagues, employees and the community to support education, and 4) personality competence, namely personal abilities that reflect a stable, stable, mature, wise and dignified personality, become role models for students, and have noble character $[5,6]$.

Student learning achievement will be achieved optimally lecturer performance in both teachings such as mastery of the material, teaching skills, teaching strategies, use of language used in delivering material, evaluation, interaction with students, and class management. Besides, students' internal factors in the form of self-satisfaction also affect their learning achievement. Thus, the variable competence of lecturers and student satisfaction affects the level of student achievement.

The problem in this study is whether there is a relationship between lecturer competence and student satisfaction in influencing learning achievement. So that the purpose of this study is to explore information and describe the relationship between lecturer competence and student satisfaction in influencing learning achievement.

\section{Methods}

The research method used is an explanatory survey. This research is included in quantitative research, where the data obtained from the sample are then analyzed according to the statistical methods used for further interpretation. The population in this study amounted to 371 respondents who were the number of students in class 2017 at the Management Study Program, Faculty of Economics, Pakuan University. By using a significant level of $10 \%$ after being calculated by the Slovin formula obtained a sample of 79 students. The data collection technique used was a questionnaire for primary data related to the variable of lecturer competence and student satisfaction, while for student achievement data used secondary data obtained from the Academic and Student Information System (SIMAK) of Pakuan University. The analytical tool used is regression analysis and correlation to determine the effect and relationship between the causal variable and the effect variable.

\section{RESULTS AND DISCUSSION}

Based on the results of data processing using SPSS (Table 2 ), it can be seen that between lecturer competence (X1) and student achievement $(\mathrm{Y})$ has a correlation value of 0.075 with a significant value of 0.513 . Thus, it can be concluded that there is no significant relationship between lecturer competence and student achievement. The relationship between student satisfaction with the learning process and learning achievement has a correlation value of 0.121 and a significant value of 
0.290. It means that there is no significant relationship between student satisfaction with the learning process and student achievement. Meanwhile, the relationship between lecturer competence and student satisfaction with the learning process has a correlation of 0.593 and a significant value of 0.000 . It can be concluded that the competence of lecturers and student satisfaction with the learning process has a significant relationship.

To know the joint correlation between lecturer competence, student satisfaction, and student achievement is shown in the following table 3 . Based on Table 3. it can be seen that the correlation between lecturer competence, student satisfaction, and student achievement is 0.110 and the coefficient of determination is 0.012 . This shows that the variation in student achievement scores can be explained by the competence of lecturers and student satisfaction by $1.2 \%$ while the remaining $98.8 \%$ is explained by other factors outside of this study. To find out the contribution of lecturer competence and student satisfaction to student achievement can be seen from the results of the following regression analysis.

TABLE II. PARTIAL CORRELATION BETWEEN LECTURER COMPETENCE, STUDENT SATISFACTION, AND STUDENT ACHIEVEMENT

\begin{tabular}{|c|c|c|c|c|c|}
\hline \multicolumn{6}{|c|}{ Correlations } \\
\hline & & & $\begin{array}{c}\text { Lecturer } \\
\text { Competence }\end{array}$ & $\begin{array}{c}\text { Student } \\
\text { Satisfaction }\end{array}$ & $\begin{array}{c}\text { Student } \\
\text { Achievements }\end{array}$ \\
\hline \multirow{9}{*}{$\begin{array}{l}\text { Spear } \\
\text { man's } \\
\text { rho }\end{array}$} & \multirow[t]{3}{*}{$\begin{array}{l}\text { Lecturer } \\
\text { Competence }\end{array}$} & $\begin{array}{l}\text { Correlation } \\
\text { Coefficient }\end{array}$ & 1.000 & $.593^{* *}$ & .075 \\
\hline & & $\begin{array}{ll}\begin{array}{l}\text { Sig. } \\
\text { tailed })\end{array} & (2- \\
\end{array}$ & . & .000 & .513 \\
\hline & & $\mathrm{N}$ & 79 & 79 & 79 \\
\hline & \multirow[t]{3}{*}{$\begin{array}{l}\text { Student } \\
\text { Satisfaction }\end{array}$} & $\begin{array}{l}\text { Correlation } \\
\text { Coefficient }\end{array}$ & $.593^{* *}$ & 1.000 & .121 \\
\hline & & \begin{tabular}{|l} 
Sig. \\
tailed)
\end{tabular} & .000 & . & .290 \\
\hline & & $\mathrm{N}$ & 79 & 79 & 79 \\
\hline & \multirow[t]{3}{*}{$\begin{array}{l}\text { Student } \\
\text { Achievements }\end{array}$} & \begin{tabular}{|l} 
Correlation \\
Coefficient
\end{tabular} & .075 & .121 & 1.000 \\
\hline & & \begin{tabular}{|ll} 
Sig. & $(2-$ \\
tailed $)$
\end{tabular} & .513 & .290 & . \\
\hline & & $\mathrm{N}$ & 79 & 79 & 79 \\
\hline
\end{tabular}

TABLE III. PARTIAL CORRELATION BETWEEN LECTURER COMPETENCE, STUDENT SATISFACTION, AND STUDENT ACHIEVEMENT

\begin{tabular}{|l|r|l|l|l|}
\hline \multicolumn{5}{|c|}{ Model Summary } \\
\hline \multirow{2}{*}{ Model } & $\boldsymbol{R}$ & $\boldsymbol{R}$ Square & $\begin{array}{c}\text { Adjusted } \boldsymbol{R} \\
\text { Square }\end{array}$ & Std. Error of the Estimate \\
\hline 1 & $.110^{\mathrm{a}}$ & .012 & -.014 & .99890 \\
\hline
\end{tabular}

a. Predictors: (Constant), Student Satisfaction, Lecturer Competence
TABLE IV. REGRESSION COEFFICIENT FOR LECTURER COMPETENCE AND STUDENT SATISFACTION ON STUDENT ACHIEVEMENT

\begin{tabular}{|c|c|c|c|c|c|c|}
\hline \multicolumn{7}{|c|}{ Coefficients $^{a}$} \\
\hline & \multirow[b]{2}{*}{ Model } & \multicolumn{2}{|c|}{$\begin{array}{c}\text { Unstandardized } \\
\text { Coefficients }\end{array}$} & \multirow{2}{*}{\begin{tabular}{|c|}
$\begin{array}{c}\text { Standardized } \\
\text { Coefficients }\end{array}$ \\
Beta \\
\end{tabular}} & \multirow[b]{2}{*}{$\mathbf{t}$} & \multirow[b]{2}{*}{ Sig } \\
\hline & & $B$ & Std. Error & & & \\
\hline \multirow[t]{3}{*}{1} & (Constant) & 2.021 & .904 & & 2.236 & .028 \\
\hline & $\begin{array}{l}\text { Lecturer } \\
\text { Competence }\end{array}$ & .001 & .005 & .017 & .118 & .906 \\
\hline & $\begin{array}{l}\text { Student } \\
\text { Satisfaction }\end{array}$ & .007 & .011 & .099 & .703 & .484 \\
\hline
\end{tabular}

a. Dependent Variable: Student Achievement

Based on Table 4, it can be seen that the contribution of lecturer competence to student achievement is 0.017 with a significant value of 0.906 , meaning that lecturer competence does not have a significant contribution to student achievement. The contribution of student satisfaction in the learning process to student achievement is 0.099 with a significant value of 0.484 , meaning that student satisfaction with the learning process does not have a significant contribution to student achievement.

\section{A. Relationship between Lecturer Competence and Student Achievement}

The findings of this study indicate that the competence of lecturers and student achievement has no significant relationship and contribution. Although most of the studies found a positive relationship, one of previous study did not find a relationship [7]. These findings suggest that higher teacher competence alone may not directly result in better academic achievement for students. Meanwhile, Abbasi and Mir from Pakistan argued that independently the ability of teachers, student work ethics and the institutional environment did not have a significant effect on student performance [8]. However, simultaneously these factors have a strong influence on student performance. Previous studies both also support insignificant results $[9,10]$. Research shows that despite high teacher quality in terms of academic and professional qualifications, it does not drive student performance. There is no significant relationship between student competence and performance.

The lack of uniformity of studies makes research on lecturer competence and student academic achievement interesting [11]. Lecturer competence is believed to be one of the important factors that contribute to student performance. However, in reality, because the learning process is complex, these meanings may vary due to several factors. This study aims to determine the relationship between the professional competence of lecturers and student academic performance. The results showed that there was no significant relationship between lecturer competence and student academic performance at the Faculty of Economics \& Business Telkom University. This means that institutions cannot rely on the competence of lecturers if they want to help develop student performance. Of course, we cannot run an educational institution with low lecturer qualifications. Competent lecturers 
are still an important aspect and are needed to help students gain more knowledge, both theory and practice. However, these results also show how important one aspect is, they cannot independently improve student performance. Lecturer competence must be considered as a tool to improve student performance. Further research is needed to be carried out in this area.

The results of this study indicate that there is no significant relationship and the contribution of lecturer competence to student achievement does not mean that lecturer competence is not important in helping improve student achievement, but lecturer competence is only one factor. As is well known, the factors that influence student achievement can be grouped into two factors, namely internal and external factors. Besides, the level of student success in the educational process is influenced by many factors. Broadly speaking, these factors can be grouped into two, namely: 1. Intellectual factors such as talent, learning capacity, intelligence, and learning outcomes that have been achieved. 2. Non-intellectual factors such as learning, career, social, emotional, gender, health, financial, personal development, family problems, use of free time, and religious and moral issues.

Lecturer competence is only one external factor among other external factors. So, it is natural if the results of this study indicate that there is no significant relationship and contribution to student achievement. Sealing that, the limitations in this study where the sample used is only 79 people. Further studies in which more variables are included and the number of samples and locations are more diverse may produce findings that are different from this study.

\section{B. Relationship between Student Satisfaction with the Learning Process and Student Achievement}

The findings of this study indicate that student satisfaction with the learning process and student achievement has no significant relationship and contribution. The results of this study are in line with previous research of which data analysis did not reveal a relationship between student satisfaction levels and student achievement [12]. Although this study did not identify whether a higher level of satisfaction was associated with a higher level of achievement on the final course examination, many factors affecting teacher and student satisfaction were identified. The data from this study also show that establishing satisfaction levels among teachers and students is universal, regardless of the level of the curriculum in which one is involved. However, further research involving multiple schools is needed to support universal satisfaction levels and the relationship between satisfaction and achievement.

McWherter examined whether there is a relationship between student satisfaction levels and student achievement [12]. Data obtained from students who participated in this survey showed that $59.7 \%$ of students were enrolled in honorslevel courses and $40.3 \%$ were enrolled in regular education classes. Current coursework the degree to which a student is enrolled is analyzed along with student satisfaction. The data do not show any relationship between the two variables. When the results were cross-tabulated, students who showed they were enrolled in the honors level course reported a satisfactionweighted average of 2.86, while those enrolled in regular education classes reported a weighted average of satisfaction of 2.82. The coefficient value, -.015, does not provide support for showing a statistical relationship between variables. The $\mathrm{R}^{2}$ value of 0.000 , indicates that $0 \%$ variance in student satisfaction can explain variations in student achievement. The p-value, .806, does not meet the threshold for statistical significance and does not indicate a relationship between student satisfaction and student achievement. When the level of courses students attended was compared with the student satisfaction survey data, no relationship was found between the two. Although students in honors-level courses reported higher feelings of success and higher levels of EOC performance, no relationship was found between levels of satisfaction. This finding contradicts current research which states that student satisfaction is positively correlated with student academic achievement [13]. Previous study also stated that satisfaction is an important aspect of student success, and higher levels of satisfaction have been reported to coincide with higher levels of academic achievement [14]. Similar to the survey of teacher results, the anonymity of students may be partly responsible for the differences between the previous study and this study. However, none of the factors contributing to student satisfaction were found to specifically influence any of the student groups associated with different curriculum levels. Researchers believe that the data from this study provide the perception that student satisfaction may be based on the overall school environment.

There is no relationship between student satisfaction in participating in the learning process and the achievements they achieve. This can occur because the factors that influence student achievement are not only satisfaction, but some factors are thought to be more influential, including intellectual factors and non-intellectual factors.

\section{Relationship between Lecturer Competence and Student Satisfaction}

The findings of this study indicate that lecturer competence and student satisfaction with the learning process have a significant relationship and contribution. Previous study defines satisfaction as individual feelings as a result of the difference between perceived and expected performance [15]. In higher education, especially as a private organization, the measurement of student satisfaction is an indicator that determines learning outcomes. process in meeting student expectations. Tough define student satisfaction as a perception or attitude toward learning activities [16]. Students will feel satisfied if they are happy or use aggressive learning attitudes, but students will feel dissatisfied if they are not happy or use passive learning attitudes.

Besides, student satisfaction refers to positive feelings associated with the institutions they attend [17]. The main factor for improving the quality of an education program is 
assessing student satisfaction. This is because student evaluations will determine the type of academic program and their professional needs. Therefore, by collecting and disseminating information about student satisfaction, adjustments will be made according to the courses offered at the tertiary institutions and the competence of lecturers [18].

Greenland investigated the factors that determine student satisfaction [19]. The respondents were business students who took four marketing modules which were taught by different instructors. 13 dimensions of classroom teaching have been identified to indicate student satisfaction. All dimensions have a significant effect on overall student satisfaction. These dimensions include lecturer knowledge, responsive lecturers, audiovisual aids, presentation standards, learning resources, course texts, class participation, student workload, learning outcomes, teaching facilities, fun, clarity, effective assignments, and module satisfaction.

The results of Gee's study show that the ten characteristics of lecturer competence are positively correlated with student satisfaction [18]. The relationship is at a moderate level. The results showed that students were satisfied when the lecturer was able to foster good relationships with students, provide assignments related to their subjects, quality lecture notes, emphasize course objectives, organize various types of class activities, ensure fairness in assessing exams, provide feedback who is useful, timely, delivers lectures clearly and broadly. Multiple regression analysis shows that there are only four variables that are significant to student satisfaction. These variables include course objectives, lecture notes, assignments, and interpersonal skills.

The results of this study are in line with previous study, statistical results show that lecturer competence has a positive and significant relationship with student satisfaction [20]. In other words, the higher the competence of the lecturers, the higher the student satisfaction in lectures. According to the theory, lecturer competence predicts student satisfaction in lectures. Therefore, it is very important for universities that are responsible for the correct education given to their students, to ensure that the lecturers of a course are capable.

\section{CONCLUSION}

Based on the results of the research, it can be drawn that he competence of lecturers and student achievement has no significant relationship and contribution. Student satisfaction with the learning process with student achievement has no significant relationship and contribution. Lecturer competence with student satisfaction with the learning process has a significant relationship and contribution.

\section{REFERENCES}

[1] Fakultas Ekonomi. (2020). Universitas Pakuan. Retrieved from https://fekonomi.unpak.ac.id/

[2] D. Retnowati, A. Fatchan and I. Astina, "Prestasi Akademik Dan Motivasi Berprestasi Mahasiswa S1 Pendidikan Geografi Universitas
Negeri Malang," Jurnal Pendidikan - Teori, Penelitian, Dan Pengembangan, vol. 1, no. 3, pp. 521-525, 2016

[3] J. Backmann, M. Weiss, M.C. Schippers and M. Hoegl, "Learning and Individual Di ff erences Personality factors, student resiliency, and the moderating role of achievement values in study progress," Learning and Individual Differences, vol. 72(April), pp. 39-48, 2019.

[4] Y. Yusof, R. Roddin and H. Awang, "What Students Need, and What Teacher Did: the Impact of Teacher' s Teaching Approaches to the Development of Students ' Generic Competences," Procedia - Social and Behavioral Sciences, vol. 204 (November 2014), pp. 36-44, 2015.

[5] Y. Alam, "Kompetensi Dosen, Motivasi Belajar Mahasiswa dan Dampaknya terhadap Prestasi Mahasiswa dalam Pembelajaran Pengantar Ekonomi (studi pada mahasiswa program studi Manajemen Informatika AMIK Bina Sriwijaya Palembang)," Jurnal Manajemen Dan Bisnis Sriwijaya, vol. 16, no. 1, pp. 23-30, 2018.

[6] D.J. García-almeida, L. Hern and P.D. Sa, "Students' perceptions of the lecturer' s role in management education: Knowledge acquisition and competence development ndez-L o. 14, pp. 411-421, 2016.

[7] R. Wamala and G. Seruwagi, "Teacher Competence and The Academic Achievement of Sixth Grade Students In Uganda," Journal of International Education Research (JIER), vol. 9, no. 1, pp. 83, 2012.

[8] A.S. Abbasi and G.M. Mir, "Impact of Teacher's Ability, Student's Work Ethics and Institutional Environment on Student Performance of University of Gujrat," Middle East Journal of Scientific Research, vol. 12, no. 4,2012

[9] A. Kosgei, J.K. Mise, O. Odera and M.E. Ayugi, "Influence of Teache Characteristics on Students' Academic Achievement among Secondary Schools," Journal of Education and Practice, vol. 4, no. 2, pp. 76-82, 2013.

[10] K.M. Bonney, "Case Study Teaching Method Improves Studen Performance and Perceptions of Learning Gains $\dagger$. Vol. 16, no. 1, pp. 21-28, 2015.

[11] A.P. Prasetio, D. Dindi, amd A.F. Fauziah, "Lecturers' Professional Competency and Students' Academic Performance in Indonesia Higher Education," International Journal of Human Resource Studies, (March), 2017

[12] S. Mcwherter, The Effects of Teacher and Student Satisfaction on Student Achievement by, 2012.

[13] J. Lim, M. Kim, S.S. Chen, and C.E. Ryder, "An empirical investigation of student achievement and satisfaction in different learning environments," Journal of Instructional Psychology, vol. 35, no. 2, pp. 113-120, 2008.

[14] K.M. Brown, A. Vincent J. Anfara, and K. Roney, "Student Achievement in High Performing, Suburban Middle Schools and Low Performing, Urban Middle Schools: Plausible Explanations for the Differences," Urban Society, vol. 36, no. 4, pp. 428-456, 2004

[15] P. Kotler, K.L. Keller, M. Brady, M. Goodman, and T. Hansen, Marketing Management. Harlow, UK: Pearson Education Limited, 2009

[16] A. Tough, Some Major Reasons for Learning. ERIC Document Reproduction, ED033251, 1982

[17] L. Hatcher, K. Kryter, J.S. Prus, and V. Fitzgerald, "Predicting College Student Satisfaction, Commitment, and Attrition from Investment Mode Constructs," Journal of Applied Social Psychology, vol. 22, pp. 1273 1296,1992

[18] N.C. Gee, "The Impact of Lecturers' Competencies on Students' Satisfaction," Journal of Arts \& Social Sciences, vol, 1, no. 2, pp. 74-86 2018.

[19] S. Greenland, "Investigating the Drivers of Student Satisfaction: The Application of Regression Analysis," Investigations in University Teaching and Learning, vol. 2, no. 2, pp. 46-53, 2005.

[20] H.H.D.N.P. Opatha, "Influence of Lecturers' Competence on Students' Satisfaction of Lecturing: Evidence for Mediating Role of Lecturing Behaviour," Universal Journal of Educational Research, vol. 8, no. 4, pp. 1167-1179, 2020 